\title{
PARIS AGREEMENT: RESPON TERHADAP PENDEKATAN PRINSIP COMMON BUT DIFFERENTIATED RESPONSIBILITIES AND RESPECTIVE CAPABILITIES DALAM KYOTO PROTOCOL
}

(Paris Agreement: A Response to an Approach of Common but Differentiated Responsibilities and Respective Capabilities Principle in Kyoto Protocol)

\author{
Amira Bilqis, Arie Afriansyah \\ Fakultas Hukum Universitas Indonesia, Depok \\ arie.afriansyah@ui.ac.id
}

Tulisan Diterima: 22-06-2020; Direvisi: 13-08-2020; Disetujui Diterbitkan: 14-08-2020

DOI:http://dx.doi.org/10.30641/dejure.2020.V20.391-408

\begin{abstract}
The ability to deal with environmental issues between developed and developing countries often impacts the respective obligation stipulated in international agreements. The principle of Common but Differentiated Responsibilities and Respective Capabilities $(C B D R-R C)$ as the leading principle in international environmental law is a bridge to balance the interests of the two groups. However, in international legal instruments, there are different implementations of these principles with each approach used. This study aims to analyze the application of the CBDR-RC principle in the Paris Agreement compared with its predecessor, the Kyoto Protocol. The research method in this paper is a normative juridical approach presented in analytical descriptive. The results identified that the Kyoto Protocol is a Top-Down approach agreement, where the reduction target is decided. Meanwhile, the successor, Paris Agreement is a Bottom-Up approach, where countries voluntarily submit their target of reducing emissions. The approach used by the Paris Agreement is different as a response to the evaluation of its predecessor. As a result, the level of participation in efforts to reduce emissions was drastically increased, and Annex I countries were encouraged to achieve higher reduction. Despite the fact that the Paris Agreement has resolved the Kyoto Protocol's issues, it still possesses some drawbacks. In conclusion, the transformation carried out in these two agreements has influenced the trend of emission reduction commitments in the climate change regime for developed and developing countries.
\end{abstract}

Keywords: common but differentiated responsibilities and respective capabilities; climate change; kyoto protocol; paris agreement

\section{ABSTRAK}

Kemampuan dalam menangani permasalahan lingkungan antara negara maju dan berkembang kerap berdampak obligasi yang diatur dalam perjanjian internasional. Prinsip Common but Differentiated Responsibilities and Respective Capabilities (CBDR-RC) sebagai prinsip yang memimpin dalam hukum lingkungan internasional merupakan jembatan untuk menyeimbangkan kepentingan dua kelompok negara tersebut. Namun, dalam instrumen hukum internasional terdapat implementasi yang berbeda dari prinsip tersebut dengan masing-masing pendekatan yang digunakan. Tujuan penelitian ini untuk menganalisa bagaimana implementasi prinsip CBDRRC dalam Paris Agreement dibandingkan dengan pendahulunya yaitu Kyoto Protocol. Metode penelitian dalam tulisan ini adalah yuridis normatif yang disajikan secara deskriptif analitis. Hasil penelitian menunjukkan bahwa pendekatan yang digunakan dalam Kyoto Protocol sebagai perjanjian yang menetapkan secara kaku besaran emisi yang harus direduksi diidentifikasi sebagai Top-Down. Sedangkan perjanjian penerusnya yaitu Paris Agreement sebagai perjanjian yang didasarkan atas dasar sukarela terhadap besaran emisi yang perlu dicapai diidentifikasi menggunakan pendekatan sebagai Bottom-Up. Pendekatan yang digunakan dari Paris Agreement berbeda sebagai respon dan bentuk evaluasi dari pendekatan yang digunakan dalam Kyoto Protocol yang berakibat tingkat partisipasi dalam usaha reduksi emisi meningkat secara drastis dan mendorong negara Annex I menargetkan reduksi yang lebih tinggi lagi. Terlepas dari kenyataan bahwa Paris Agreement telah menyelesaikan masalah dalam mekanisme Kyoto Protocol, perjanjian ini masih memiliki beberapa kekurangan. Kesimpulannya, transformasi pendekatan yang terjadi dalam kedua perjanjian ini mempengaruhi tren komitmen reduksi emisi dalam rezim perubahan iklim bagi negara maju maupun berkembang.

Kata kunci: prinsip tanggung jawab bersama tapi beda; kyoto protocol; paris agreement; perubahan iklim 


\section{PENDAHULUAN}

Instrumen hukum lingkungan internasional terkait perubahan iklim terus berkembang sejak berlakunya United Nations Framework Convention on Climate Change (UNFCCC) ${ }^{1}$ di tahun 1994. Kedudukan UNFCCC sebagai framework treaties $^{2}$ memungkinkan adanya instrumen hukum lain yang bersifat komplementer yang tidak dapat dipisahkan seperti protokol, lampiran serta bentuk perjanjian lainnya untuk menegosiasikan, menambah atau merevisi perjanjian awal tersebut. Kumpulan perjanjian tersebut menghasilkan rezim perubahan iklim. Dalam perkembangannya, UNFCCC sukses menghasilkan sebuah protokol dan perjanjian baru yang menjadi bagian integral dari UNFCCC yaitu Kyoto Protocol dan Paris Agreement.

Terbentuknya konvensi ini mencerminkan bahwa telah ada kepedulian dan rasa tanggung jawab bersama dalam mengatasi masalah perubahan iklim global. Sekaligus mengakui bahwa terdapat ketimpangan antara negara maju dan berkembang. Sebagaimana tertera dalam UNFCCC:

Acknowledging that the global nature of climate change calls for the widest possible cooperation by all countries ... in accordance with their common but differentiated responsibilities and respective capabilities and their social and economic conditions. ${ }^{3}$

Diikuti dengan salah satu pasalnya mengatur:

The Parties should protect the climate ... in accordance with their common but differentiated responsibilities and respective capabilities. Accordingly, the developed country Parties should take the lead in combating climate change and the adverse effects thereoft.

$1 \quad$ United Nations (UN), United Nations Framework Convention on Climate Change (United Nations Treaty Series, 1992), Annex 1.

2 Perjanjian yang disepakati hanya terdiri dari hal yang lebih umum seperti menjabarkan prinsipprinsip secara luas serta menyediakan aturan teknis. Konvensi dan protokol yang lebih rinci dapat mengisi kekosongan aturan yang ada. Bentuk perjanjian ini dibuat agar tindakan selanjutnya mudah diidentifikasi dan menciptakan rezim pengaturan yang lebih besar.

3 United Nations (UN), United Nations Framework Convention on Climate Change, Konsideran Alinea Ketiga.

4 Ibid., Ps. 3.
Konvensi ini mencoba mengakomodasi dua kepentingan yang berbeda dengan ide awal bahwa negara maju dapat memimpin pergerakan terhadap perlindungan lingkungan dilatarbelakangi dengan adanya kontribusi yang lebih besar terhadap perubahan iklim secara historis, serta melimpahnya sumber daya finansial dan teknologi. Sedangkan negara berkembang juga diikutsertakan untuk dapat secara bersama menanggulangi permasalahan ini walaupun memiliki fokus kepentingan lain yaitu pembangunan ekonomi dan sosial. ${ }^{5}$ Oleh sebab itu diperlukan pembedaan kontribusi ${ }^{6}$. Kerja sama internasional menjadi sangat penting serta cukup rumit untuk dapat menjembatani kemampuan antara negara industri yang sudah maju dan negara berkembang. Dengan adanya prinsip Common but Differentiated Responsibilities and Respective Capabilities (CBDR-RC) dalam UNFCCC diharapkan kerja sama internasional terkait perubahan iklim dapat lebih optimal karena permasalahan ini berkaitan dengan common pool resources yaitu sumber daya yang tidak dimiliki secara khusus oleh suatu negara dan dapat digunakan oleh pihak mana pun.

CBDR-RC merupakan salah satu prinsip hukum lingkunganinternasional ${ }^{7}$ yang berkembang dari Stockholm Declaration ${ }^{8}$ dan Resolusi 44/228 yang menyatakan bahwa negara maju bertanggung jawab terhadap masalah lingkungan secara global didasarkan pada tanggung jawab historis serta kapabilitasnya ${ }^{10}$. Dalam Stockholm Conference prinsip CBDR-RC tertera dalam alinea pembuka Stockholm Declaration yaitu "The protection and

5 Diana Yusyanti, “Tindak Pidana Pembakaran Hutan dan Lahan oleh Korporasi untuk Membuka Usaha Perkebunan," Jurnal Penelitian Hukum De Jure 19, no. 4 (2019): 462.

6 Kevin A. Baumert dan Nancy Kete, "Introduction: An Architecture for Climate Protection," in Building on the Kyoto Protocol: Options for Protecting the Climate, ed. J. Baumert, K., Blanchard, O., Llosa, S. and Perkaus (Washington DC: World Resources Institute, 2002), 33, http://pdf.wri.org/opc_full.pdf.

7 Philippe Sands, Principles of International Environmental Law, 2nd ed. (Cambridge: Cambridge University Press, 2003).

8 Lavanya Rajamani, "The changing fortunes of differential treatment in the evolution of international environmental law," International Affairs 88, no. 3 (2012): 605-623.

9 Majelis Umum Perserikatan Bangsa-Bangsa, Resolusi 44/228 (1989), 22 Desember 1989, par. 14.

10 Majelis Umum Perserikatan Bangsa-Bangsa, Resolusi 44/228 (1989), par. 14. 
improvement of the human environment (...) it is the urgent desire of the peoples of the whole world and the duty of all Governments." 11 Sekaligus menyatakan adanya kewajiban yang berbeda bertuliskan:

(...) it will be essential in all cases to consider the systems of values prevailing in each country, and the extent of the applicability of standards which are valid for the most advanced countries but which may be inappropriate and of unwarranted social cost for the developing countries ${ }^{12}$.

Perkembangan prinsip ini, khususnya dalam rezim perubahan iklim terdapat perbedaan implementasi dalam perjanjian turunan UNFCCC khususnya dalam Kyoto Protocol (1997) dan Paris Agreement (2015). Diawali dengan implementasinya dalam Kyoto Protocol, Paris Agreement seakan hadir untuk menjawab kekurangan dari implementasi CBDR-RC dan pendekatannya. Walaupun begitu, keduanya merupakan instrumen hukum yang memiliki karakteristik yang sama sehingga dijadikan fokus utama dalam penulisan ini. Selain, memiliki akar perjanjian yang sama yaitu UNFCCC, Kyoto Protocol dan Paris Agreement masing-masing tertulis dalam dokumennya mengenai prinsip hukum lingkungan internasional yang digunakan yaitu CBDR-RC. Dalam Kyoto Protocol, prinsip tersebut tertulis dalam Pasal 10:

All parties, taking into account their common but differentiatied responsibilities and their specific national and regional development priorities, objectives and circumstances, without introducing any new commitments for parties not included in Annex $1^{13}$.

Sedangkan dalam Paris Agreement dinyatakan dalam Pasal 2 (2) tertulis "This Agreement will be implemented to reflect equity and the principle of common but differentiated responsibilities and respective capabilities, in the

United Nations (UN), United Nations Conference on the Human Environment Stockholm Declaration: A/CONF.48/14/Rev.1, 1973, https://www.un.org/ ga/search/view_doc.asp?symbol=A/CONF.48/14/ REV.1.

12 Ibid, Prinsip ke-23.

13 United Nations (UN), Kyoto Protocol of the united nations framework convention on climate change (United Nations Treaty Series 2303, 2005), [selanjutnya disebut Kyoto Protocol], Ps.10 light of different national circumstances ${ }^{\prime \prime}$.

Dalam menerapkan prinsip ini pada masingmasing perjanjian, terdapat dua tolak ukur yaitu target yang perlu dicapai dan kekuatan mengikat atau obligasi yang dimintakan oleh perjanjian tersebut terhadap tiap negara anggota. Perbedaan berupa satuan target menjadi alasan yang nyata karena nantinya berpengaruh pada mekanisme dalam masing-masing instrumen. Dalam Kyoto Protocol, satuan target yang digunakan adalah Quantified Emission Limitation and Reduction Commitment (QELRC) sedangkan dalam Paris Agreement tidak ada satuan yang digunakan secara sama namun seluruh Nationally Determined Contribution (NDC) memiliki parameternya masing-masing.

Dengan pengaturan dalam perjanjiannya masing-masing, terdapat pendekatan yang berbeda digunakan untuk dapat memenuhi prinsip CBDR$\mathrm{RC}$ dan bagaimana tolak ukur masing-masing differentiated responsibilities bagi negara anggota. Menurut Todd Stern, Kyoto Protocol merupakan perjanjian yang didasarkan dengan pendekatan top-down ${ }^{15}$ sedangkan menurut Christina Voigt dan Felipe Ferreira, Paris Agreement dianggap sebagai perjanjian dengan konsep yang lebih seimbang dibandingkan dengan pendahulunya dengan penggunaan pendekatan bottom-up ${ }^{16}$.

Berdasarkan latar belakang diatas, tulisan ini menganalisa konsep penting, prinsip Common but Differentiated Responsibilities and Respective Capabilities (CBDR-RC). Selain itu, tulisan ini juga memperbandingan implementasi prinsip CBDR-RC dalam Kyoto Protocol dan Paris Agreement implikasi perbedaan implementasi dari keduanya.

Berdasarkan kumpulan pengaturan dan data yang dikumpulkan diharapkan tulisan ini dapat memberikan manfaat bagi masyarakat dan pihak yang berkepentingan dan sebagai bentuk sumbangan terhadap ilmu pengetahuan terkhusus

14 United Nations (UN), Paris Agreement, United Nations (United Nations Treaty Series 54113, 2015), [selanjutnya disebut Paris Agreement], Ps. 2(2).

15 Todd Stern, "The Paris Agreement and its Future," The Brookings Institute 5 (2018): 7.

16 Christina Voigt dan Felipe Ferreira, "Dynamic Differentiation: The Principles of CBDR-RC, Progression and Highest Possible Ambition in the Paris Agreement," Transnational Environmental Law 5, no. Fifth Anniversary Issue (2016): 285. 
pada ilmu hukum mengenai hukum lingkungan internasional.

Literatur yang ada berfokus pada elaborasi prinsip CBDR-RC secara definitif dan/atau implementasi prinsip pada salah satu perjanjian saja. Sedangkan tulisan ini akan menjelaskan secara komprehensif dari bagaimana CBDR- RC diimplementasikan dalam kedua perjanjian turunan UNFCC yaitu Kyoto Protocol dan Paris Agreement serta mengidentifikasikan perbedaan pendekatan yang digunakan dalam masingmasing mekanisme pemenuhan perjanjian tersebut. Sebagai tambahan, tulisan ini juga akan membandingkan keduanya. Diharapkan dengan adanya elaborasi tersebut, dapat diidentifikasi implikasi dari implementasi prinsip tersebut dalam hukum internasional.

Tulisan ini bertujuan untuk menganalisa bagaimana implementasi prinsip CBDR-RC dalam Paris Agreement dibandingkan dengan pendahulunya yaitu Kyoto Protocol dimana keduanya memiliki karakteristik prinsip CBDRRC, yaitu Top-Down Approach dan BottomUp Approach. Parameter analisis yang akan digunakan adalah cara perhitungan target masingmasing, kekuatan mengikat serta institusi untuk Monitoring, Reporting and Verification (MRV).

Penelitian ini akan membahas tiga poin diawali dengan memberikan gambaran terkait prinsip CBDR-RC. Diikuti dengan elaborasi mekanisme yang digunakan dalam Kyoto Protocol dan Paris Agreement untuk dapat mengimplementasikan prinsip CBDR-RC. Tulisan ini akan berfokus hanya pada mekanisme Clean Development Mechanism (CDM) dalam Kyoto Protocol karena hanya mekanisme ini yang menghendaki partisipasi negara berkembang. Terakhir, tulisan ini akan memberikan penjelasan perbandingan implementasi prinsip CBDR-RC dan masing-masing pendekatan yang digunakan. Penggunaan istilah Top-Down Approach dan Bottom-Up Approach digunakan untuk menggambarkan kerangka pendekatan yang berbeda terkait kebijakan internasional mengenai perubahan iklim. Indikator perbandingan yang akan digunakan di limitasi yaitu bagaimana penentuan target, keterikatan hukum atas target individual suatu negara anggota, bagaimana mekanisme MRV, dan jumlah negara yang memiliki target reduksi emisi.

\section{METODEPENELITIAN}

Jenis penelitian ini adalah yuridis normatif yang menggunakan metode penulisan berupa studi kepustakaan di mana penulisan ini didasarkan pada penelaahan bahan-bahan kepustakaan, dokumen, hingga literatur yang relevan dengan pembahasan materi. Berdasarkan sifatnya, penulisan penelitian ini disusun dengan pendekatan deskriptif-analisis, di mana penelitian ini didasarkan pada penggambaran prinsip CBDRRC secara umum yang kemudian dianalisis berdasarkan implementasi dalam lingkup hukum internasional. Dalam tulisan ini akan berfokus pada dua perjanjian internasional mengenai perubahan iklim yaitu Kyoto Protocol dan Paris Agreement. Jenis data yang digunakan terdiri dari bahan hukum primer, bahan hukum sekunder serta bahan hukum tersier.

\section{PEMBAHASAN DANANALISIS}

\section{A. Pengertian Common but Differentiated Responsibilities and Respective Capabilities (CBDR-RC)}

Dalam menyelesaikan permasalahan lingkungan khususnya perubahan iklim dengan sifatnya yang lintas batas diperlukan kerja sama dari seluruh negara. Dalam prosesnya hal ini tidak dapat dicapai dengan mudah karena negara memiliki kedaulatan masing-masing yang setara. Meskipun ada kewajiban internasional yang tertulis dalam suatu perjanjian tetap saja kekuatan mengikatnya hanya didasarkan pada sukarela negara anggota perjanjian tersebut ${ }^{17}$. Negara-negara ini faktanya memiliki beberapa faktor pembeda seperti perbedaan kekayaan, kekuasaan, dan pengaruh antar negara serta sifat masalah lingkungan yang berbeda-beda, semuanya menentukan apakah masalah tersebut akan memunculkan rezim internasional yang efektif dalam agenda internasional ${ }^{18}$. Dengan adanya perbedaan tersebut maka dalam lingkup hukum internasional dikenal dengan Common but Differentiated Responsibilities and Respective Capabilities (CBDR-RC) yang sejarah

17 Robert Jenningsdan ArthurWatts, ed., Oppenheim's International Law (New York: Longman, 1996).

18 Farhana Yamin dan Joanna Depledge, The International Climate Change Regime: A Guide to Rules, Institutions and Procedures (Cambridge: Cambridge University Press, 2004). 
terbentuknya terdiri dari dua elemen berbeda yaitu Common Responsibility (tanggung jawab bersama) dan Differentiated Responsibilities (tanggung jawab yang berbeda).

Common Responsibility berakar dari prinsip sederhana yaitu kerja sama negara di mana negara melakukan integrasi bersama untuk mencapai suatu tujuan bersama ${ }^{19}$. Menurut Phillippe Sands elemen ini didasarkan atas common pool resources - sumber daya yang tidak dimiliki secara khusus oleh suatu negara dan dapat digunakan oleh pihak mana pun, sehingga diperlukan kerja sama untuk melestarikan keberlanjutan dari sumber daya tersebut ${ }^{20}$. Sedangkan elemen Differentiated Responsibilities didasarkan pada dorongan untuk mempertimbangkan keadaan-keadaan yang berbeda apabila dikaitkan pada isu lingkungan terdapat perbedaan kontribusi masing-masing negara dalam kemampuannya untuk mencegah, mengurangi dan mengendalikan ancaman lingkungan ${ }^{21}$.

Saat ini konsep CBDR-RC berada dalam beberapa instrumen hukum internasional seperti United Nations Framework Convention on Climate Change (UNFCCC), Montreal Protocol, Rio Declaration, Kyoto Protocol, dan Paris Agreement sehingga dapat dinyatakan mendapat pengakuan dan implementasi yang luas dalam perjanjian lingkungan internasional. Walaupun dalam menyatakan CBDR-RC sebagai prinsip yang benar dan dapat digunakan sebagai dasar pengaturan dalam hukum internasional terdapat perdebatan. Ada yang menyebut kedudukan CBDR-RC sebagai prinsip hukum lingkungan internasional $^{22}$, ada juga pendapat ahli yang menyatakan penyebutan CBDR-RC sebagai prinsip adalah tidak sesuai. ${ }^{23} \mathrm{Di}$ lain sisi, ada ahli yang menyatakan CBDR-RC merupakan kebiasaan hukum internasional namun pendapat

19 Edith Brown Weiss, "Environmental Equity: The Imperative for the Twenty-first Century," in Sustainable Development and International Law, ed. W. Lang (London: Martinus Nijhoff Publishers, 1995).

20 Sands, Principles of International Environmental Law, 286.

$21 \quad$ Ibid, 287.

22 Ibid.231.

23 Lavanya Rajamani, "The principle of common but differentiated responsibility and the balance of commitments under the climate regime," Review of European Community and International Environmental Law 9, no. 2 (200o): 124. lain menyatakan belum karena tidak berlaku secara universal $^{24}$. Meskipun ada perselisihan status hukum dari CBDR-RC, tulisan ini melihat bahwa gagasan ini merupakan prinsip yang memimpin dan patut digunakan dalam perkembangan rezim perubahan iklim di masa depan sebagaimana suatu soft law menjadi suatu pedoman untuk hukum di masa depan. ${ }^{25} \mathrm{Hal}$ ini dilatarbelakangi dengan penulisan dan penggunaan prinsip ini dalam berbagai instrumen hukum lingkungan internasional.

Definisi CBDR-RC yang secara umum yang digunakan oleh Farhana dan Joana dalam bukunya yaitu:

Prinsip hukum lingkungan internasional yang digunakan untuk merujuk pada permasalahan tertentu, dalam hal ini perubahan iklim, yang dipengaruhi dan mempengaruhi seluruh negara ataupun setidaknya ditingkat yang sama dan hal tersebut menghasilkan suatu tanggung jawab yang perlu dibedakan karena tidak seluruh negara perlu untuk berkontribusi secara sama untuk dapat menyelesaikan isu perubahan iklim. ${ }^{26}$

Pandangan ahli lain terkait definisi CBDRRC lebih kurang sesuai dengan definisi yang dirumuskan diatas.

\section{B. Implementasi CBDR-RC dalam Kyoto Protocol}

Conference of the Parties (COP) ke-3 dari UNFCCC di Kyoto, Jepang mengadopsi Kyoto Protocol pada 11 Desember 1997 yang mulai berlaku pada 16 Februari 2005. Dalam hal ini Kyoto Protocol berperan sebagai perjanjian tambahan dari UNFCCC sebagai framework treaties $^{27}$. Kyoto Protocol secara umum dibagi atas dua periode yang berbeda, yaitu periode pertama dan kedua. Namun, periode kedua tidak berjalan sesuai dengan rencana melalui Doha

24 D. Freestone, "The Road from Rio: International Environmental Law after the Earth Summit," Journal of Environmental Law 6, no. 2 (1994), 199.

25 Vita Cita Emia Tarigan dan Eka N.A.M Sihombing, "Kebijakan Pengendalian Pencematan di Selat Malaka yang bersumber dari Kecelakaan Kapal," Jurnal Penelitian Hukum De Jure 19, no. 4 (2019): 484.

26 Yamin dan Depledge, The International Climate Change Regime: A Guide to Rules, Institutions and Procedures, 69.

27 Ved P. Nanda dan George Rock Pring, International Environmental Law and Policy for the 21st Century, 2nd ed. (Leiden: Martinus Nijhoff Publishers, 2013). 
Amendement. Dalam komitmen periode pertama yang diselenggarakan antara tahun 2008 hingga 2012, negara anggota diminta untuk mengurangi total emisi gas rumah kaca sebesar 5\% dari tingkat emisi pada tahun $1990^{28}$. Oleh sebab itu, Kyoto Protocol dianggap sebagai perjanjian serta instrumen hukum yang paling ambisius di masanya ${ }^{29}$.

Penetapan target penurunan emisi gas rumah kaca dalam protokol ini menggunakan istilah Quantified Emission Limitation and Reduction Commitment (QELRC) yang mengacu pada target yang perlu dicapai oleh beberapa negara yang ditetapkan dalam Annex B Protocol Kyoto ${ }^{30}$. Penetapan negara anggota dalam Annex B Kyoto Protocol diadaptasi dari daftar nama negara yang tertera dalam Annex I UNFCCC yang kategori negaranya terdiri dari negara industri yang menjadi anggota Organisation for Economic Co-operation and Development (OECD) tahun 1992, negara yang ekonominya dalam transisi serta Federasi Rusia, Negara-Negara Baltik dan beberapa negara Eropa. ${ }^{31}$ Walaupun diadaptasi dari Annex I UNFCCC, terdapat perbedaan negara dengan tambahan Liechtenstein, Slowakia dan Slovenia.

Dengan adanya pembedaan tersebut maka istilah negara maju dan berkembang diidentikan dengan Negara Annex I dan Negara Non-Annex I. Kategorisasi ini memudahkan perjanjian internasional setelah UNFCCC untuk membebankan tanggung jawab terhadap negara yang bersangkutan. Diferensiasi ini merupakan wujud implementasi prinsip CBDR-RC di implementasikan dalam protokol ini sebagaimana tertulis dalam Pasal 10. Saat ini telah ada 191 negara dan Uni Eropa yang menjadi anggota dari perjanjian tersebut ${ }^{32}$.

Setiap negara yang tercantum pada Annex B pada dasarnya memiliki dua jenis target untuk dapat memenuhi tujuan umum pada Pasal 3 yaitu: target yang dibedakan untuk setiap anggota Annex

\section{Kyoto Protocol, Ps. 3(1).}

29 Sebastian Oberthur dan Hermann E.Ott, The Kyoto Protocol: International Climate Policy for the 21st Century (Berlin: Springer, 1999), 95.

30 Kyoto Protocol, Annex B.

31 Kyoto Protocol, Ps.1(7).

32 UNFCCC, "The Kyoto Protocol - Status of Ratification," diakses Juni 22, 2019, https:// unfccc.int/process/the-kyoto-protocol/status-ofratification.
I (target individual) dan target kolektif. ${ }^{33}$ Target individual didapat dengan mendistribusikan usaha yang diperlukan untuk dapat mencapai target kolektif sebesar 5 (lima) persen dengan perhitungan yang telah diatur dalam Pasal 3.7, 3.8 dan Keputusan 19/CP.7 yang menghasilkan assigned amounts untuk setiap negara anggota ${ }^{34}$. Keputusan 19/CP.7 pada dasarnya menyatakan assigned amount tiap negara akan sama dengan persentase QELRC yang tertera dalam daftar Annex B dengan cara menghitung sumber emisi gas rumah kaca oleh negara tersebut yang tertera dalam Annex A dikali 5. ${ }^{35}$

Assigned amount untuk setiap negara hingga komitmen berakhir dibagi-bagi dalam beberapa unit, yaitu: emission reduction unit (ERU), certified emission reduction (CER), assigned amount unit (AAU), dan removal unit (RMU). Dengan adanya pembagian ini, tiap negara anggota dapat menghasilkan, membatalkan, memperoleh atau mentransfer emisi yang diizinkan oleh protokol sehingga berpengaruh pada naik atau turunnya jumlah yang dibebankan. Seluruh pembagian unit ini disebut dengan Kyoto Units dan pengaturannya bergantung pada mekanisme dan jenis masingmasing unit. ${ }^{36}$ Unit ERU digunakan dalam mekanisme Joint Implementation (JI), sedangkan unit AAU digunakan dalam mekanisme Emissions Trading (ET). Untuk unit CER digunakan dalam Clean Development Mechanism (CDM), satu-satunya mekanisme yang dibentuk untuk kerjasama negara Annex I dan Non-Annex I.

Secara eksplisit obligasi yang dirumuskan dalam protokol ini ditujukan hanya untuk negara Annex I. Sedangkan peranan negara non-annex I yang disediakan oleh Kyoto Protocol cenderung lebih "pasif" dengan hanya keterkaitan dalam mekanisme CDM sebagaimana tertera dalam Pasal 12 dantidak memiliki kewajibanuntukmengurangi

33 UNFCCC, "Technical Paper for UNFCCC "Tracing the Origins of the Kyoto Protocol: an Article-byArticle Textual History FCCC/TP/200o/2," 2000, par.131 dan 216.

34 Yamin dan Depledge, The International Climate Change Regime: A Guide to Rules, Institutions and Procedures, 120.

35 United Nations (UN), "Report on the Conference of the Parties on its Seventh Session Addendum Part Two: Action Taken by the Conference of Parties FCCC/CP/2001/13/Add.2," 2002.

36 UNFCCC, Kyoto Protocol Reference Manual on Accounting of Emissions and Assigned Amount (2008): 14 . 
emisi secara langsung ${ }^{37}$. Hal ini membuktikan bahwa Kyoto Protocol menetapkan tanggung jawab kepada negara secara menyeluruh namun tetap membedakan peranan antara kelompok negara maju dan negara berkembang walaupun pendekatan top-down yang tersentralisasi pada suatu institusi.

Bagi negara Annex I untuk mencapai assigned amount yang diberikan terdapat salah satu faktor penting yaitu ketersediaan lahan geografis untuk dapat melaksanakan proyekproyek reduksi emisi. Menimbang bahwa lokasi untuk melakukan tindakan pengurangan Gas Rumah Kaca (GRK) tidaklah relevan karena ini merupakan permasalahan lintas batas dan untuk mengefektifkan biaya yang lebih murah untuk mitigasi maka diperlukan suatu ide untuk mempermudah implementasinya. Salah satu ide yang dihasilkan adalah tindakan mitigasi yang dilakukan dapat dilakukan di mana pun di dunia. Oleh sebab itu, Kyoto Protocol mengatur tiga mekanisme kontribusi terdiri dari mekanisme pasar berbasis proyek yaitu Joint Implementation (JI) dan Clean Development Mechanism (CDM) serta Emission Trading System (ET). Skema perdagangan emisi ini dianggap memberikan "keleluasaan" bagi negara annex I untuk dapat memenuhi kewajiban mereka di luar dari perbatasan negara mereka.

Dengan tingkat kompleksitas regulasinya yang tinggi, protokol ini tidak langsung dapat dilaksanakan namun perlu beberapa waktu untuk para pihak beradaptasi ${ }^{38}$. Didukung dengan pengadopsian Marrakesh Accords di tahun yang 2001 sebagai kerangka teknis untuk dapat mengimplementasikan regulasi protokol ini. Walaupun kompleks, dari 36 negara yang berpartisipasi dalam Kyoto Protocol pada periode pertama hanya 9 negara yang tidak berhasil mengurangi emisi domestik dari yang

37 Christian Almer dan Ralph Winkler, "Analyzing the Effectiveness of International Environmental Policies: The Case of the Kyoto Protocol," Journal of Environmental Economics and Management 82 (2017): 126.

38 Christopher N Maccracken et al., "The Economics of the Kyoto Protocol Source: The Energy Journal , Vol . 20 , Special Issue : The Costs of the Kyoto Protocol : A Multi-Model Evaluation ( 1999 ), pp . 25-71 Published by : International Association for Energy Economics Stable URL : https:/" 20 (1999): 25-71, http://www.jstor.org/stable/23296905. dimintakan. ${ }^{39}$ Dengan mekanisme yang diatur dalam Kyoto Protocol diatas dapat diidentifikasi bahwa pendekatan yang digunakan memenuhi karakteristik Top-Down. Top-Down Approach merupakan istilah pendekatan yang digunakan dalam sebuah perjanjian yang memiliki dasar keanggotaan multilateral atau universal. Terdapat tiga karakteristik utama yang dimiliki oleh pendekatan ini. Pertama, sistem operasionalnya identik dengan "targets and timetables" ditetapkan oleh suatu badan yang mewakili negara anggota terhadap suatu perjanjian internasional tersebut ${ }^{40}$. Teori ini menganggap bahwa implementasi dari suatu peraturan didasarkan pada keputusan lembaga otoritas ${ }^{41}$. Kedua, terdapat badan yang menetapkan pembagian secara jelas. Lazimnya menentukan bagaimana cara untuk dapat memenuhi target dari perjanjian dengan menentukan jadwal dan target yang mengikat bagi negara anggota ${ }^{42}$. Dalam kasus yang ekstrim pendekatan top-down yang kuat identik dengan adanya koordinasi global yang rigid dan terpusat untuk dapat mencapai tujuan berdasarkan aturan yang disepakati bersama. ${ }^{43}$ Ketiga, dengan adanya penentuan tersebut dari waktu ke waktu akan muncul kekuatan yang mengikat secara hukum terhadap para pihak untuk dapat memenuhi kewajiban yang diberikan oleh badan tersebut. Hal ini dapat dilakukan dengan Monitoring, Reporting, and Verification (MRV) yang kuat serta tersedianya mekanisme kepatuhan ${ }^{44}$.

Sedangkan dalam pengaturan Kyoto Protocol identik dengan ketiga karakteristik dari pendekatan

39 Igor Shishlov, Romain Morel, dan Valentin Bellassen, "Compliance of the Parties to the Kyoto Protocol in the First Commitment Period," Climate Policy 16, no. 6 (2016): 770.

40 Rafael Leas Arcas, "Top-down Versus Bottom-Up Approaches for Climate Change Negotiations: An Analysis," The IUP Journal of Governance and Public Policy 6, no. 4 (2011): 8.

41 Frank Fischer, Gerald J. Miller, dan Mara S. Sidney, ed., Handbook of Public Policy Analysis: Theory, Politics, and Methods (Boca Raton: CRC Press, 2017), 91.

42 Robert O. Keohane dan David G. Victor, "After the failure of top-down mandates: The role of experimental governance in climate change policy," Towards a Workable and Effective Climate Regime 14 (2015): 202.

43 William Hare et al., "The architecture of the global climate regime: A top-down perspective," Climate Policy 10, no. 6 (2010): 601. 
top-down. Kyoto Protocol memiliki COP dan CMP yang berkedudukan sebagai badan terpusat yang memiliki agenda negosiasi dan pembahasan mengenai implementasi protokol tersebut dan kerap diidentifikasi sebagai badan yang mewakili seluruh negara anggota ${ }^{45}$. Keduanya berfungsi sebagai badan yang menentukan alokasi emisi dari tiap negara anggota sebagaimana diatur dalam Pasal 7(4) Kyoto Protocol yang menyatakan "...The Conference of the Parties serving as the meeting of the Parties to this Protocol shall also, prior to the first commitment period, decide upon modalities for the accounting of assigned amounts". Fungsi ini menempatkan COP dan CMP menjadi pertemuan yang penting dalam menentukan target individualnya sehingga disebut sebagai mekanisme Top-Down Approach karena alurnya yang dihasilkan dari badan yang lebih superior (COP dan CMP) ke bawah (negara anggota). Dengan dibantu The Subsidiary Body for Scientific and Technological Advice (SBSTA) dan the Subsidiary Body for Implementation (SBI) dalam penentuan masing-masing target. Badanbadan ini secara khusus memperkuat sentralisasi dari implementasi dari Kyoto Protocol sekaligus memenuhi elemen pertama dan kedua dari pendekatan top-down.

Target-target yang dinegosiasikan dua bulan sebelum diselenggarakannya COP ke-3, diberikan kepada negara Annex I yang bersifat mengikat secara hukum ${ }^{46}$. Hal ini didukung dengan mekanisme MRV yang kuat melalui Joint Implementation Supervisory Committee (JISC) bertugas untuk mengawasi verifikasi ERU yang dihasilkan oleh proyek yang mengikuti prosedur JI, sedangkan Clean Development Mechanism Executive Board (CDM EB) mengawasi mekanisme CDM serta bertugas untuk menyiapkan keputusan untuk COP dan CMP sekaligus melakukan akreditasi operational entities. Terakhir, Compliance Committee terdiri dari dua cabang yaitu facilitative branch yaitu badan yang memberikan saran dan bantuan untuk dapat membantu negara anggota patuh pada

45 Yamin dan Depledge, The International Climate Change Regime: A Guide to Rules, Institutions and Procedures, 425 .

46

David G Victor, The Collapse of the Kyoto Protocol and the Struggle to Slow Global Warming A Council on Foreign Relations Book, Princeton University Press (Berkeley: Princeton University Press, 2001), 27-28. regulasi dan enforcement branch bertanggung jawab untuk menentukan konsekuensi bagi para pihak yang tidak memenuhi komitmen yang telah dialokasikan. Ketiga badan tersebut menunjukkan tersedianya mekanisme kepatuhan dari tiap skema yang diatur dalam Kyoto Protocol dan memenuhi elemen terakhir yaitu eksistensi mekanisme MRV dari pendekatan top-down.

Dalam praktiknya, protokol ini memang tidak seluruhnya mengimplementasikan pendekatan topdown secara ekstrim. Seperti halnya mekanisme yang diatur dalam Kyoto Protocol, walaupun diperlukan hasil yang spesifik dalam mencapai pengurangan emisinya namun dengan adanya 3 (tiga) mekanisme tersebut, dimungkinkan adanya cara yang fleksibel untuk mencapai tujuan protokol. ${ }^{47}$ Tulisan ini mengidentifikasi bahwa seharusnya COP dan CMP menentukan bagaimana cara yang rigid untuk dapat memenuhi objektif UNFCCC dan protokol apabila disamakan dengan konsep top-down secara keseluruhan. Namun, tulisan ini sependapat dengan para ahli yang menyatakan bahwa walaupun tidak serupa secara keseluruhan, Kyoto Protocol telah memenuhi karakteristik utama dari pendekatan top-down.

Di sisi lain, Kyoto Protocol dan pendekatan top-down ini tidak lepas dari kekurangan. Pendekatan ini cenderung satu arah ke bawah yang berdampak pada negara non-annex I yang merasa tidak adanya perlakuan adil terkait penentuan komitmen emisi ${ }^{48}$. Hal ini didasarkan pada aspek procedural equity bahwa negara nonannex I tidak memiliki bargaining power dalam proses negosiasi penentuan komitmen ${ }^{49}$. Tidak hanya itu, mekanisme CDM memiliki kelemahan yang dapat mencederai kepercayaan antara dua kelompok negara sebagai wujud prinsip CBDRRC dengan tidak adanya standar kredit untuk dapat memastikan apakah proyek tersebut akan menghasilkan CER yang asli atau palsu..$^{50}$

47 Raymond J Kopp, "The Climate has Change-so Must Policy," U.S Global Leadership: An initiative of the Center for Climate and Electricity Policy Issue Brief 11, no. 3 (2011).

48 Almer dan Winkler, "Analyzing the Effectiveness of International Environmental Policies: The Case of the Kyoto Protocol," 125

49 Baumert dan Kete, "Introduction: An Architecture for Climate Protection."19.

50 Michael Wara, "Measuring the Clean Development Mechanism's erformance and Potential," UCLA Law Review 55, no. 6 (2004): 1768. 
Pembagian kelompok negara ini juga memiliki kritisi dari kedua belah pihak. Negara maju seperti Amerika Serikat, Jepang, Australia, dan negara lain sejenis menganggap bahwa kurangnya komitmen untuk mengontrol emisi bagi negara berkembang menjadikan usaha negara Annex I sia-sia. ${ }^{51}$ Selain itu, mereka berpendapat bahwa dengan tindakannya untuk berkomitmen mengenai pengurangan emisi gas rumah kaca seperti yang diamanatkan oleh UNFCCC dan Kyoto Protocol serta memberikan bantuan dana kepada negara berkembang merupakan upaya yang cukup. Oleh sebab itu, negara industri meminta negara berkembang untuk setidaknya menyatakan niat untuk berkontribusi walaupun langkahlangkah kecil mengingat pentingnya sifat kolektif untuk menyelesaikan masalah lingkungan ${ }^{52}$.

Sedangkan negara berkembang justru menyatakan bahwa terdapat kurangnya kredibilitas dalam hal penekanan emisi gas rumah kaca melalui kerja sama internasional yang dilakukan oleh negara industri mengingat hampir seluruh emisi tersebut disebabkan aktivitas manusia di negara industri. ${ }^{53}$ Selain itu, negara berkembang memiliki prioritas lain seperti memberantas kemiskinan dan kesehatan masyarakat dimana fokus utama negara-negara ini adalah bagaimana perubahan iklim berdampak pada produksi makanan dan kemajuan ekonomi di negaranya. ${ }^{54}$ Perbedaan kontribusi ini yang menjadikan adanya konsep CBDR-RC dalam Kyoto Protocol sebagaimana tertulis dalam Pasal 10.

Untuk dapat memahami bagaimana mekanisme kontribusi dalam Kyoto Protocol baik bagi negara Annex I dan Non-Annex I, berikut penjelasan mengenai Clean Development Mechanism (CDM).Pada dasarnya mekanisme ini merupakan gabungan dari JI dan ET yang tertulis dalam Pasal 12 Kyoto Protocol, dilakukan antara negara Annex I dan Non-Annex I dengan syarat mendukung pembangunan keberlanjutan

51 Nicole Grunewald dan Inmaculada Martinez Zarzoso, "Did the Kyoto Protocol fail? An Evaluation of the Effect of the Kyoto Protocol on $\mathrm{CO}_{2}$ Emissions," Environment and Development Economics 21, no. 1 (2016): 10.

52 Nada Maamoun, "The Kyoto Protocol: Empirical Evidence of a Hidden Success," Journal of Environmental Economics and Management 95 (2019): 230. Ibid.
Ibid. di negara penyelenggara proyek (host country). Mekanisme yang dibentuk berfokus pada negara Non-Annex I untuk dapat berpartisipasi dalam melaksanakan pembangunan berkelanjutan dalam kontribusinya terhadap objektif dari UNFCCC. Selain dengan tujuan itu, proyek ini dapat memberikan kesempatan kepada negara Annex I untuk melaksanakan proyeknya tanpa terhambat masalah lahan. Bentuk mekanismenya pun dapat dilakukan dalam berbagai cara dan tidak melimitasi aktor yang melaksanakan proyek di negara NonAnnex I sehingga pelaksana dapat berupa badan hukum atau pemerintah setempat. CDM memiliki tujuan untuk mengikutsertakan investasi dari sektor swasta untuk mengambil langkah kearah proyek yang ramah terhadap iklim.

Dengan skema investasi ini, negara Annex I dapat memperoleh unit CER yang dapat digunakan untuk memenuhi komitmen yang dimintakan oleh protokol. CER dihitung setara dengan satu ton karbon dioksida yang dinilai, divalidasi dan diverifikasi oleh CDM Executive Board. Sedangkan dalam tingkat nasional harus mendapat persetujuan dari badan tingkat nasional yaitu Designated National Authority (DNA) yang bertugas untuk menilai apakah proyek tersebut akan menguntungkan pembangunan keberlanjutan dan masyarakat lokal atau tidak. Dengan adanya CER ada kemungkinan untuk negara investor dapat mengurangi perhitungan alokasi emisi yang diatur dalam Kyoto Protoco ${ }^{55}$.

Disaat skema CDM membantu negara annex I untuk memenuhi kewajibannya juga di lain sisi membantu negara non-annex I dalam menjalankan pembangunan berkelanjutan. Namun, tidak seluruh proyek dapat dihitung menjadi CER hanya yang dapat memenuhi standar sertifikasi yang ditetapkan saja sehingga proyek yang terlibat biasanya besar. ${ }^{56}$ Kewajiban masing-masing pihak diatur dalam Pasal 11. Dalam Pasal ini diatur mengenai mekanisme finansial bagi negara berkembang yang sedang mencoba menjalankan komitmen Kyoto Protocol untuk dibiayai oleh negara Annex I ${ }^{57}$.

55 Victor, The Collapse of the Kyoto Protocol and the Struggle to Slow Global Warming A Council on Foreign Relations Book, 28

56 UNFCCC, Kyoto Protocol Reference Manual on Accounting of Emissions and Assigned Amount, November 2008

57 Kyoto Protocol, Ps. 11 Ayat 2 poin a 


\section{Implementasi CBDR-RC dalam Paris Agreement}

Paris Agreement yang diadopsi pada tanggal 12 Desember 2015 saat COP ke-21 di Paris seakan membuka peluang besar atas kegagalan Doha Amendement. Objektif dari perjanjiannya ini adalah untuk menjaga kenaikan temperatur global di bawah $2^{\circ} \mathrm{C}$ dan berupaya untuk membatasi meningkatnya suhu untuk tidak melewati $1.5^{\circ} \mathrm{C}$ sebelum masa revolusi industri dengan harapan mengurangi risiko dan dampak dari perubahan iklim ${ }^{58}$. Pada tanggal 4 November 2016, perjanjian ini mulai berlaku saat Tiongkok, Amerika Serikat ${ }^{59}$ dan India sebagai tiga dari empat negara penghasil GRK terbesar yang apabila di akumulasi mencapai 42\% dari total seluruhnya bergabung dengan Paris Agreement.

Paris Agreement memiliki dasar konsep ambition and progression yang dihasilkan dari salah satu pertemuan negosiasi yang ter gambarkan dalam tujuan jangka panjang dalam perjanjian tersebut. ${ }^{60}$ Konsekuensi dari ditulisnya secara jelas batas $1.5^{\circ} \mathrm{C}$ adalah melebarnya cakupan dari usaha yang dilakukan oleh negara yang meratifikasi perjanjian ini, tidak hanya mencakup mitigasi namun adaptasi dan dukungan ${ }^{61}$. Dalam negosiasinya pun tetap terdapat perbedaan pendapat antara negara maju dan negara berkembang. Negara maju yang memiliki orientasi dalam mitigasi berpendapat bahwa tujuan jangka panjang hanya berbentuk batas suhu dan menyatakan implikasi dari batas tersebut untuk mengurangi GRK secara global. Sedangkan negara berkembang berpendapat bahwa perlu adanya penyamarataan dengan peningkatan dukungan dalam hal keuangan,

58 Paris Agreement, Ps. 2 (1) (a)

59 Donald Trump, Presiden Amerika Serikat, melalui pidatonya per tanggal 1 Juni 2017 menyatakan keluar dari Paris Agreement. Lihat juga Roger Harrabin, "Paris Agreement: Trump confirms US will leave climate accord," BBC News, 2019.

6 UNFCCC, "Decision 1/CP.17 FCCC/ADP/2015/1," in Ad Hoc Working Group on the Durban Platform for Enhanced Action Second Session FCCC/ADP/20, 2015, 3 .

61 Lavanya Rajamani dan Emmanuel Guerin, "Central Concepts in the Paris Agreement and How They Evolved," in The Paris Agreement on Climate Change: Analysis and Commentary, ed. Daniel R. Klein (New York: Oxford University Press, 2017), 75. teknologi dan pengembangan kapasitas ${ }^{62}$. Oleh sebab itu fokusnya menjadi penyamarataan antara mitigasi dan adaptasi.

Dalam perkembangan rezim perubahan iklim, prinsip CBDR-RC dalam UNFCCC dan Kyoto Protocol menjadi suatu hal yang kontroversial dan diketahui berkontribusi besar dalam gagalnya Kyoto Protocol ${ }^{63}$. Negara maju yang termasuk dalam Annex I, konsisten untuk menolak diferensiasi yang didasarkan pada daftar nama negara di Annex yang dirasa statis dan responsif terhadap perkembangan ekonomi. Sebagaimana India dan Tiongkok sebagai salah dua penghasil polusi terbesar tidak termasuk dalam Annex I yang diberikan target oleh protokol.

Prinsip CBDR-RC dalam Paris Agreement tersurat dalam Pasal 2Ayat 2 namun dalam beberapa bagian dari perjanjian ini juga secara tersirat dinyatakan. Berdasarkan Paris Agreement yang menyatakan "Also recognizing the specific needs and special circumstances of developing country Parties, especially those that are particularly vulnerable ...." ${ }^{64}$ dan "Taking full account of the specific needs and special situations of the least developed countries with regard to funding and transfer of technology." Diikuti dengan yang tertulis dalam Pasal 3:

The efforts of all Parties will represent a progression over time, while recognizing the need to support developing country Parties for the effective implementation of this Agreement.$^{65}$

Dengan adanya prinsip CBDR-RC tertanam dalam Paris Agreement, perjanjian ini pula mengatur mekanismenya dengan pertimbangan pada hak istimewa tiap negara terhadap otonomi yang berdaulat dan menghormati keadaan yang ada di tingkat nasional. Mekanisme yang dibentuk adalah Nationally Determined Contributions (NDC) yang berisi komitmen negara anggota untuk mengurangi emisi nasional dan beradaptasi terhadap dampak perubahan iklim secara individual ${ }^{66}$. Mekanisme ini menjadi bentuk nyata bahwa telah ada pergeseran dari categorical binary approach, pembagian negara berdasarkan kategori UNFCCC.${ }^{67}$ Komitmen tiap negara yang

$\begin{array}{ll}62 & \text { Ibid, } 76 \\ 63 & \text { Ibid, 82 } \\ 64 & \text { Paris Agreement, Preamble } \\ 65 & \text { Paris Agreement, Ps. } 3 \\ 66 & \text { Paris Agreement, Ps.4(2)(3) } \\ 67 & \text { Izzet Ari dan Ramazan Sari, "Developing CBDR- }\end{array}$


berbentuk NDC merupakan target yang akan terus diperbaharui per 5 (lima) tahun sekali dengan tiap mengumpulkan target yang baru, harus lebih tinggi.

Dengan bentuk target yang ditetapkan berdasarkan self-diagnosis dalam kondisi nasional dan kemampuan dari suatu negara, kemudian dikenal konsep non-backsliding dan ratchet-up mechanism. ${ }^{68}$ Konsep non-backsliding awalnya diketahui tertulis dalam Lima Decision ${ }^{69}$. Dalam negosiasi di Lima, pemikiran akan konsep tersebut diawali dengan non-backsliding sebuah konsep yang berkembang atas kekhawatiran negara-negara maju tersebut tidak mengisi NDC dengan ambisi yang lebih rendah daripada yang ditargetkan melalui Kyoto Protocol $^{70}$. Negosiasi tersebut kemudian menghasilkan pula principle of progression and highest possible ambition secara langsung tertulis dalam Pasal 4 Ayat 3 Paris Agreement di mana negara anggota diminta untuk memberikan NDC secara progresif dengan tetap mempertimbangkan kapabilitas negaranya melalui prinsip CBDR-RC ${ }^{71}$. Oleh sebab itu, selain membandingkan target reduksi dengan perjanjian internasional pendahulunya ada pula prinsip yang digunakan untuk adanya target progresif antar siklus Paris Agreement.

Dalam ratchet-up mechanism, Bodansky menyatakan mekanisme tersebut digunakan untuk mempromosikan NDC agar lebih progresif dengan siklus 5 tahun serta tiga elemen yaitu: ${ }^{72}$ a) Global Stocktakes yang dihasilkan dari pertemuan

$\mathrm{RC}$ indices for fair allocation of emission reduction responsibilities and capabilities across countries," Cogent Environmental Science 3 (2017): 15.

68 Annalisa Savaresi, "The Paris Agreement: a New Beginning?," Journal of Energy \& Natural Resources Law 34, no. 1 (2016): 22.

69 UNFCCC, "Lima call for climate action," Decision COP 20 (2014): 1-43, https://unfccc.int/files/ meetings/lima_dec_2014/application/pdf/ auv_cop2o_lima_call_for_climate_action.pdf, [selanjutnya disebut Lima Decision], para 66 dan 79 .

70 Rajamani dan Guerin, "Central Concepts in the Paris Agreement and How They Evolved.”, 78

71 LavanyaRajamanidanJuttaBrunnée, “Thelegalityof downgrading nationally determined contributions under the Paris agreement: Lessons from the US disengagement," Journal of Environmental Law 29, no. 3 (2017): 544.

72 Daniel Bodansky, "The Paris Agreement: A New Hope?," American Journal of International Law 110, no. 2 (2016): 288-319. antar negara anggota untuk menilai kemajuan secara kolektif yang dilaksanakan tiap 5 tahun sekali; b) Kewajiban setiap negara anggota untuk berkomunikasi atas NDC masing-masing setiap 5 tahun sekali; c) Adanya ekspektasi dari tiap negara anggota untuk membuat NDC yang progresif dari yang lalu dan atas dasar ambisi tertinggi yang dapat dilakukan. Kombinasi NDC dan konsep "no backsliding" kemudian mengakomodasi diferensiasi antara negara maju dan berkembang dengan titik awal yang berbeda untuk memasang ambisinya.

Dengan baru berlakunya Paris Agreement beberapa tahun silam dan baru dilaksanakan pengumpulan NDC sebanyak satu kali mengingat COP26, dimana negara akan mengumpulkan NDC kedua, diundur akibat pandemic COVID$19^{73}$ maka belum banyak perkembangan dari mekanisme kontribusi disini. Namun, Pasal 6 Paris Agreement membuka peluang kerjasama untuk dapat mencapai NDC masing-masing. Kerjasama yang tercantum dalam Pasal tersebut sepenuhnya sukarela dan dapat membuat aksi iklim menjadi lebih efisien. Terdapat tiga mekanisme kerjasama yang tertulis, yaitu: Cooperative approaches, the UNFCCC-governed crediting mechanism, dan the Framework for Non-Market Approaches ${ }^{74}$.

Tulisan ini mencatat bahwa pendekatan yang digunakan Paris Agreement memenuhi karakteristik bottom-up dengan tiga karakteristik yang diidentifikasi dari pendekatan top-down ${ }^{75}$. Teori ini terbentuk sebagai respon kritis atas pendekatan sebelumnya yang menunjukkan karakteristik yang berbanding terbalik karena target besar, mengikat secara rigid, dan sistem MRV yang berbelit. Dengan pendekatan yang baru ini, perhitungan target yang didasarkan pada kemampuan negara menunjukkan ketiadaan kewajiban rigid dari suatu otoritas dan negara memiliki kekuasaannya masing-masing. Tulisan ini juga mengidentifikasi bahwa dengan keluwesan yang ditawarkan oleh Paris Agreement berupa penulisan target bersifat voluntary dan tidak terlalu mengikat melalui dokumen NDC

73 UNFCCC, "COP26: Postponed," last modified 2020, https://unfccc.int/news/cop26-postponed.

74 Andrew Howard, "Voluntary Cooperation," in The Paris Agreement on Climate Change: Analysis and Commentary, ed. Daniel R. Klein (New York: Oxford University Press, 2017), 178.

75 Hare et al., "The architecture of the global climate regime: A top-down perspective," 601 
yang didepositkan pada sekretariat, mendorong tingginya partisipasi negara untuk bergabung. Serta, mekanisme MRV yang dianugerahkan pada negara sesuai dengan karakteristik top-down mendukung adanya kompetisi antarnegara untuk memiliki sistem MRV terpercaya secara global.

Gagasan ini menolak untuk mendefinisikan kebijakan datang dari tingkat pusat dan menganggap kebijakan yang dibuat oleh negara sebagai birokrat lokal lebih menguntungkan karena dianggap lebih mengetahui realita yang ada. ${ }^{76}$ Pendekatan ini diidentik dengan hanya akan memiliki sedikit atau bahkan tidak ada koordinasi upaya global yang kemudian diikuti dengan koordinasi terbatas. Target yang ingin dicapai tidak ditentukan menggunakan negosiasi atau pemusatan melainkan hanya didasarkan pada janji secara unilateral. Oleh sebab itu, tingkat akuntabilitas dan kepatuhan memiliki spektrum penilaiannya cenderung berbeda pada masingmasing pihak. Keterikatan dari setiap janjinya pun memiliki strata yang berbeda karena tidak adanya mekanisme kepatuhan yang secara rigid ada dalam Top-Down.

Pada intinya memberikan kesempatan negara untuk berjanji melakukan tindakan tertentu. Aturan mengenai MRV disepakati dengan adanya penyesuaian antara negara maju dan berkembang. Dalam melakukan pemantauan perkembangan dan konsekuensi ketidakpatuhan hanya akan dilaksanakan pada tingkat domestik. Perjanjian ini pun dapat mengikat secara hukum. Paris Agreement dalam hal memenuhi karakteristik inti dari pendekatan bottom-up telah dianggap terpenuhi dilihat dari bentuk target yang dinyatakan secara sepihak oleh negara yang bersangkutan walaupun implementasi pendekatan ini tidak menyeluruh ${ }^{77}$.

Mekanisme NDC pada dasarnya meminta untuk memasang target ambisi setinggi mungkin, dengan adanya pembedaan antar kelompok negara yang ditetapkan melalui konsep "nobacksliding". ${ }^{78}$ Dengan adanya pernyataan yang dilakukan secara unilateral, tulisan ini melihat kedudukan Conference of Parties to the Paris Agreement (CMA) sebagai lembaga tertinggi dan yang mengatur perjanjian ini bersifat lebih Policy Analysis: Theory, Politics, and Methods, 92

78 Paris Agreement, Ps.4 pasif dengan meninjau implementasi dari Paris Agreement dan secara berkala mencatat NDC masing-masing negara. Selain itu, CMA juga bertugas untuk menilai kemajuan secara kolektif terhadap pencapaian tujuan perjanjian ini dan juga jangka panjang ( global stocktake). Dalam Decision 1/ CP.21, dinyatakan pula bahwa CMA memiliki tugas untuk membangun komunikasi terkait adaptasi, registrasi adaptasi dan hal-hal tambahan lainnya. Oleh sebab itu, CMA lebih berfungsi sebagai penyimpanan dan pemantauan daripada sebagai wadah koordinasi global walaupun tetap ada fungsi itu dalam pertemuan CMA.

Terakhir adanya mekanisme MRV di tingkat domestik sebagai acuannya, hal ini dikarenakan NDC yang diajukan berisi target secara nasional dan berbentuk uraian langkah-langkah sehingga tiap negara anggota memiliki standarnya masingmasing. Dengan adanya sistem pelaporan wajib oleh nasional yang mencakup informasi mengenai emisi yang dihasilkan dan yang berhasil diserap, mekanisme ini bertumpu pada transparansi negara dan kepercayaan antara pihak untuk melakukan peninjauan. ${ }^{79}$ Walaupun isi uraiannya secara garis besar sama yaitu berisi uraian upaya nasional yang mengarah pada pembangunan yang rendah emisi serta climate-resilient dan mengidentifikasi kebijakan dan praktik yang secara khusus dapat diimplementasikan untuk dapat mencapai target yang dituju. Walaupun berbeda-beda, namun CMA selaku badan tertinggi tetap melakukan pengawasan secara global dan nantinya dapat melakukan peninjauan terhadap masing-masing NDC.

\section{Perbandingan dan Implikasi Implementasi CBDR-RC}

Dengan latar belakang pembedaan kontribusi di Kyoto Protocol dengan bentuk pembedaan negara maju dan berkembang, yang tertulis secara rigid dalam pembagian negara Annex I/ Annex B dan Non-Annex I. Hal ini kemudian menimbulkan permasalahan yang diangkat oleh negara Annex I bahwa pembagian tersebut terlalu memisahkan kewajiban dari negara anggota protokol. Sedangkan dalam Paris Agreement berkembangnya pembedaan tersebut menambah pembedaan kelompok-kelompok negara yang lebih spesifik seperti least developed countries of International Climate Politics," 1116 
(LDC) dan small island developing states (SIDS). Keduanya tertulis dalam beberapa Pasal di Paris Agreement sebagai faktor yang perlu dipertimbangkan saat menjalankan perjanjian ini. Selain itu, terdapat istilah kelompok negara tambahan yang digunakan pula dalam mengambil suatu tindakan terkait dengan pendanaan, asuransi, dan transfer teknologi. Hal ini dilatarbelakangi untuk mengetahui kebutuhan spesifik dari negaranegara yang kemungkinan besar terkena dampak buruk dari perubahan iklim atau dampak dari implementasi tindakan adaptasi. Setelah mengetahui bagaimana pembedaan kelompok dalam masing-masing instrumen perlu diketahui bahwa keduanya memiliki pendekatan yang berbeda.

Dalam Kyoto Protocol, QELRC telah ditentukan sejak awal yang dibagi kepada negara Annex B protokol dalam bentuk mengikat secara hukum. Pembagian ini dilakukan menggunakan pendekatan top-down, seluruh target yang perlu dicapai dilakukan dengan menghitung proyeksi berapa banyak emisi GRK yang dapat dilepas untuk mencapai 5\% di bawah tahun 1990 dan kemudian dibagi kepada beberapa negara yang berada dalam Annex I UNFCCC. Proyeksinya apabila seluruh negara Annex B memenuhi QELRCnya maka akan tercapai target yang tercantum dalam Pasal 3 . Target yang ditentukan bukan berasal dari anggota maupun kesepakatan bersama, melainkan terbagi dari objektif protokol yang kemudian dilakukan koordinasi secara global dan aktif oleh badan tertingginya yaitu CMP dan badan tambahan lainnya untuk melaksanakan MRV dari kegiatankegiatan atas dasar protokol.

Paris Agreement memiliki pendekatan yang sangat berkebalikan dengan Kyoto Protocol yaitu pendekatan bottom-up. Hal ini dilakukan dengan target yang dimiliki tiap negara berupa pernyataan komitmen negara masing-masing yang dinyatakan melalui NDC. Berbeda dengan kedudukan Annex $\mathrm{B}$ yang merupakan bagian integral dari protokol sehingga bersifat mengikat secara hukum, NDC hanya sebatas komitmen di tingkat internasional yang tidak memiliki keterikatan secara hukum. Namun, NDC memiliki kelebihan yaitu partisipasi aktif dari negara berkembang dapat dilakukan, mengingat mekanisme ini dilakukan secara unilateral sehingga negara-negara tersebut dapat mengukur kemampuan dan melihat kondisi secara nasional untuk dapat menyatakan komitmennya.
Konsep NDC ini menyediakan fleksibilitas yang tinggi dalam mengatur reduksi emisi yang diinginkan oleh negara yang mengeluarkannya serta didukung dengan konsep no backsliding. Hal ini merupakan salah satu wujud pembedaan dalam Paris Agreement selain perbedaan target tiap negara tetapi standar komitmennya pun dibedakan dengan negara Annex B dalam Paris Agreement untuk berkomitmen lebih dibandingkan dalam Kyoto Protocol. Serta diikuti dengan adanya pembedaan secara halus terhadap negara industri dan negara berkembang terhadap kelompok negara tertentu seperti Least Developed Countries (LDC) terkait climate finance dan/atau prosedur secara spesifik seperti linimasa ${ }^{80}$.

Dalam analisis yang dilakukan oleh Pieter Pauw, dkk menyatakan bahwa dalam hal mitigasi negara maju cenderung memasang target absolut dan cenderung lebih tinggi terkait pengurangan emisinya. Hal ini diketahui sebagai implikasi dari perbedaan pendekatan yang digunakan dimana penghasil emisi besar yang sebelumnya menghalangi kemajuan negosiasi dan sekarang terbuka untuk mendukung karena fleksibilitas yang ditawarkan. ${ }^{81}$ Dibandingkan negara berkembang di angka $16 \%$ dan LDC serta SIDS 9\%. ${ }^{82} \mathrm{Hal}$ ini sesuai dengan ketentuan dalam Paris Agreement yang meminta negara maju untuk dapat memimpin dalam menjalankan komitmennya ${ }^{83}$.

Pembedaan lainnya selain no backsliding adalah climate finance, capacity building, dan transfer teknologi. Dalam urusan pembiayaan, diketahui bahwa $60 \%$ negara berkembang berkomitmen untuk menjalankan mitigasi apabila dibiayai oleh dana bantuan internasional sedangkan kelompok LDC dan SIDS pada 80\%. ${ }^{84}$ Hal ini tertera dalam NDC yang diserahkan pada sekretariat, biasanya dikenal dengan target bersyarat (conditional target) dan target tak

8o Pieter Pauw, Kennedy Mbeva, dan Harro van Asselt, "Subtle differentiation of countries' responsibilities under the Paris Agreement," Palgrave Communications 5, no. 1 (2019): 2, http:// dx.doi.org/10.1057/s41599-019-0298-6.

81 Falkner, "The Paris Agreement and the New Logic of International Climate Politics," 1114

82 Pauw, Mbeva, dan van Asselt, "Subtle differentiation of countries' responsibilities under the Paris Agreement," 3

83 Paris Agreement, Ps.4(4)

84 Pauw, Mbeva, danvan Asselt, "Subtledifferentiation of countries' responsibilities under the Paris Agreement," 4 
bersyarat (unconditonal target), dimana target bersyarat merujuk pada target yang ditargetkan tercapai apabila ada bantuan yang diberikan dari komunitas internasional sedangkan target tak bersyarat adalah target yang dituliskan tanpa adanya bantuan dari pihak eksternal suatu negara. Biasanya negara berkembang menuliskan dua jenis target dalam NDC nya. Data tersebut pada intinya menunjukkan bahwa masing-masing NDC memiliki kondisi yang berbeda-beda dengan tetap dipimpin oleh negara maju.

Tabel 1.

Perbandingan Target Negara Annex I dan NonAnnex I dalam Kyoto Protocol dan Paris Agreement

\begin{tabular}{|c|c|c|c|}
\hline $\begin{array}{l}\text { Nama } \\
\text { Negara }\end{array}$ & \begin{tabular}{|l} 
Kyoto \\
Protocol \\
(QELRC)
\end{tabular} & $\begin{array}{l}\text { Paris Agreement } \\
\text { (NDC) }\end{array}$ & Keterangan \\
\hline \multicolumn{4}{|c|}{ Negara Annex I/Annex B } \\
\hline Kanada & 94 & $\begin{array}{l}30 \% \text { di } \\
\text { tahun } 2030 \\
\text { dibandingkan } \\
\text { tahun } 2005\end{array}$ & $\begin{array}{l}\text { Revisi } \\
\text { NDC telah } \\
\text { dikumpulkan }\end{array}$ \\
\hline Jepang & 94 & $\begin{array}{l}26 \% \text { di tahun } \\
2030\end{array}$ & $\begin{array}{l}\text { Dibandingkan } \\
\text { di tahun } 2013 \\
\text { dalam reduksi } \\
\text { sebesar } 25.4 \% \\
\end{array}$ \\
\hline Belanda & 92 & \begin{tabular}{|l}
$40 \%$ di \\
tahun 2030 \\
dibandingkan \\
tahun 1990
\end{tabular} & $\begin{array}{l}\text { Target NDC } \\
\text { didasarkan } \\
\text { pada target } \\
\text { akumulatif } \\
\text { oleh Uni } \\
\text { Eropa } \\
\end{array}$ \\
\hline \multicolumn{4}{|c|}{ Negara Non-Annex I } \\
\hline Kosta Rika & - & $\begin{array}{l}\text { Maks. 9,374,000 } \\
\text { T CO }{ }^{2} \text { eq di } \\
\text { tahun } 2030 \text { dan } \\
\text { pengurangan } \\
\text { emisi } \\
\text { sebesar 25\% } \\
\text { dibandingkan } \\
\text { tahun } 2012 \\
\end{array}$ & \\
\hline Maroko & - & $\begin{array}{l}42 \% \text { di bawah } \\
\text { tingkat BAU di } \\
\text { tahun } 2030\end{array}$ & \\
\hline Indonesia & - & $\begin{array}{l}29-41 \% \text { di } \\
\text { bawah tingkat } \\
\text { BAU di tahun } \\
2030\end{array}$ & \\
\hline
\end{tabular}

Tabel di atas menunjukkan adanya konsep no backsliding dari negara Annex I Kyoto Protocol dan target negara berkembang yang ambisius setelah diikutsertakan secara langsung dalam mekanisme dalam Paris Agreement. Walaupun belum semua negara berkembang memasang target secara absolut berbentuk angka, namun partisipasi dari negara berkembang perlu diapresiasi. Dengan fleksibilitas dan kelebihan yang ada, patut diketahui bahwa tidak adanya mekanisme MRV secara global membuat Paris Agreement rawan akan data yang bersifat bias karena dihasilkan dan distandarisasi oleh negara anggota masingmasing.

Apabila dibandingkan dalam Kyoto Protocol, assigned amount diberikan hanya dengan mengukur GDP serta emisi historisnya, selain faktor tersebut tidak dipertimbangkan lebih jauh lagi. Protokol ini pula tidak memberikan negara berkembang akses langsung untuk berkontribusi, melainkan menyediakan mekanisme kontribusi kerja sama berbentuk CDM yang memerlukan partisipasi negara Annex B pula. Walaupun, Paris Agreement memiliki tingkat partisipasi negara yang tinggi namun apabila dijumlahkan seluruh NDC tersebut masih tidak dapat memenuhi target bersama untuk menjaga perubahan iklim ditingkat yang dapat dikelola. Perlu digarisbawahi bahwa keduanya mengimplementasikan masing-masing pendekatan tidak hingga ke tahap ekstrem namun menyerupai sebagian besar karakteristik utama dari top-down dan bottom-up approach .

\section{KESIMPULAN}

Prinsip Common but Differentiated Responsibilities and Respective Capabilities (CBDR-RC) merupakan prinsip terkemuka dalam rezim perubahan iklim. Prinsip ini didefinisikan sebagai prinsip yang membebankan tanggung jawab yang berbeda atas kepemilikan bersama dalam hal ini berlaku bagi perlindungan lingkungan. Prinsip ini terdapat dalam Kyoto Protocol dan Paris Agreement yang masingmasing memiliki karakteristik prinsip CBDR-RC yang berbeda yaitu adanya perbedaan pendekatan yang digunakan. Perbedaan ini memicu banyaknya kritik akan Top-Down approach yang digunakan dalam Kyoto Protocol sehingga Second Commitment Period dari protokol tersebut tidak dapat dilanjutkan.

Top-down approach dan bottom-up approach merupakan perbedaan pendekatan yang kemudian menghasilkan implikasi pada masing-masing isntrumen. Faktor yang membedakan antara lain: Pertama, kewajiban negara, dimana Kyoto Protocol membebankan kewajiban hanya pada sekelompok negara Annex I namun berubah menjadi terbuka kepada seluruh negara untuk dapat berkontribusi secara langsung. Khususnya 
bagi negara berkembang tanpa harus melalui mekanisme CDM.

Kedua, cara perhitungan target masingmasing yang berbeda, dalam Kyoto Protocol dilakukan dengan menghitung berapa reduksi yang diperlukan dan dibagi berdasarkan catatan historis emisi dari negara tersebut. Kemudian berubah dalam Paris Agreement, target yang dipasang diinisiasi oleh negara yang nantinya akan terikat pada negara tersebut. Diikuti dengan mekanisme rachet-up mechanism yang mendorong adanya target yang lebih tinggi lagi setiap 5 tahun sekali.

Terakhir, kekuatan mengikat serta institusi MRV yang berbeda dalam Kyoto Protocol kekuatan mengikat dari target tersebut tergolong kuat karena target tersebut ditetapkan oleh lembaga otoritatif dan tertulis dalam Annex protokol. Didukung dengan adanya mekanisme kepatuhan yang jelas dan rigid melalui JISC, CDM EB, dan Compliance Committee. Sedangkan dalam Paris Agreement, cenderung lebih lemah karena target yang dipasang merupakan target yang dikeluarkan oleh negara yang bersangkutan. Diperparah dengan MRV yang hanya dilakukan oleh negara dalam bentuk laporan tahunan yang dikumpulkan ke CMA.

Tulisan ini mengidentifikasi pula bahwa implikasi perbedaan implementasi prinsip CBDRRC dalam Paris Agreement menghasilkan jumlah partisipasi negara, khususnya negara berkembang, dalam mendeklarasikan target reduksi emisi meningkat secara drastis. Serta, mekanisme NDC secara sukarela mendorong negara Annex I dalam Kyoto Protocol cenderung mengumpulkan target yang lebih tinggi. Hal ini dapat digarisbawahi bahwa mekanisme ini efektif untuk meningkatkan partisipasi negara yang diharapkan diikuti dengan tingginya implementasi untuk menekan laju perubahan iklim.

Selain memberikan pengaruh positif dalam rezim perubahan iklim patut diingat bahwa sifat perjanjian yang sangat fleksibel dan voluntary ini rentan akan lambatnya kemajuan dan tingkat kepatuhan yang rendah. Oleh sebab itu, tulisan ini melihat adanya celah yang patut direvisi agar dapat memaksimalkan kelebihan dari pendekatan bottom-up dalam Paris Agreement.

\section{SARAN}

Terbentuknya rezim baru dalam perubahan iklim melalui Paris Agreement sebagai respon dari runtuhnya Kyoto Protocol masih belum dapat diakui sepenuhnya karena masih terdapat banyak kekurangan. Walaupun pendekatan yang digunakan sangat menunjang banyak negara untuk ambil andil, perlu ada beberapa perubahan. Dengan adanya target yang dibentuk melalui NDC yang diajukan oleh negara tersebut. Oleh sebab itu, tulisan ini menyarankan perlu adanya mekanisme "naming and shaming" dengan adanya sistem periodically updated ranking sebagai solusi penerapan MRV tanpa perlu melibatkan CMA secara penuh. Hal ini dapat diidentifikasi sebagai hybrid approach yang diharapkan akan menciptakan dorongan untuk memenuhi Paris Target.

\section{DAFTAR KEPUSTAKAAN}

Almer, Christian, dan Ralph Winkler. "Analyzing the Effectiveness of International Environmental Policies: The Case of the Kyoto Protocol." Journal of Environmental Economics and Management 82 (2017): 125-151.

Arcas, Rafael Leas. "Top-down Versus BottomUp Approaches for Climate Change Negotiations: An Analysis." The IUP Journal of Governance and Public Policy 6, no. 4 (2011): 7-52.

Ari, Izzet, dan Ramazan Sari. "Developing CBDR$\mathrm{RC}$ indices for fair allocation of emission reduction responsibilities and capabilities across countries." Cogent Environmental Science 3 (2017): 1-19.

Baumert, KevinA., dan Nancy Kete. "Introduction: An Architecture for Climate Protection." In Building on the Kyoto Protocol: Options for Protecting the Climate, diedit oleh J. Baumert, K., Blanchard, O., Llosa, S. and Perkaus, 33. Washington DC: World Resources Institute, 2002. http://pdf.wri.org/opc_full.pdf.

Bodansky, Daniel. "The Paris Agreement: A New Hope?" American Journal of International Law 110, no. 2 (2016): 288-319. 
Falkner, Robert. "The Paris Agreement and the New Logic of International Climate Politics." International Affairs 92, no. 5 (2016): 11071125.

Fischer, Frank, Gerald J. Miller, dan Mara S. Sidney, ed. Handbook of Public Policy Analysis: Theory, Politics, and Methods. Boca Raton: CRC Press, 2017.

Freestone, D. "The Road from Rio: International Environmental Law after the Earth Summit." Journal of Environmental Law 6, no. 2 (1994).

Grunewald, Nicole, dan Inmaculada Martinez Zarzoso. "Did the Kyoto Protocol fail? An Evaluation of the Effect of the Kyoto Protocol on $\mathrm{CO} 2$ Emissions." Environment and Development Economics 21, no. 1 (2016): 1-22.

Hare, William, Claire Stockwell, Christian Flachsland, dan Sebastian Oberthür. "The architecture of the global climate regime: A top-down perspective." Climate Policy 10, no. 6 (2010): 600-614.

Harrabin, Roger. "Paris Agreement: Trump confirms US will leave climate accord." $B B C$ News, 2019.

Howard, Andrew. "Voluntary Cooperation." In The Paris Agreement on Climate Change: Analysis and Commentary, diedit oleh Daniel R. Klein. New York: Oxford University Press, 2017.

Jennings, Robert, dan Arthur Watts, ed. Oppenheim's International Law. New York: Longman, 1996.

Keohane, Robert O., dan David G. Victor. "After the failure of top-down mandates: The role of experimental governance in climate change policy." Towards a Workable and Effective Climate Regime 14 (2015): 201-212.

Kopp, Raymond J. "The Climate has Change-so Must Policy." U.S Global Leadership: An initiative of the Center for Climate and Electricity Policy Issue Brief 11, no. 3 (2011).

Maamoun, Nada. "The Kyoto Protocol: Empirical Evidence of a Hidden Success." Journal of Environmental Economics and Management 95 (2019): 227-256.
Maccracken, Christopher N, James A Edmonds, Son H Kim, D Ronald, Christopher N Maccracken, James A Edmonds, dan Son $\mathrm{H}$ Kim. "The Economics of the Kyoto Protocol Source: The Energy Journal, Vol . 20 , Special Issue: The Costs of the Kyoto Protocol : A Multi-Model Evaluation ( 1999 ), pp . 25-71 Published by : International Association for Energy Economics Stable URL : https:/" 20 (1999): 25-71. http://www. jstor.org/stable/23296905.

Nanda, Ved P., dan George Rock Pring. International Environmental Law and Policy for the 21st Century. 2nd ed. Leiden: Martinus Nijhoff Publishers, 2013.

Oberthur, Sebastian, dan Hermann E.Ott. The Kyoto Protocol: International Climate Policy for the 21 st Century. Berlin: Springer, 1999.

Pauw, Pieter, Kennedy Mbeva, dan Harro van Asselt. "Subtle differentiation of countries' responsibilities under the Paris Agreement." Palgrave Communications 5, no. 1 (2019): 1-7. http://dx.doi.org/10.1057/s41599-0190298-6.

Rajamani, Lavanya. "The changing fortunes of differential treatment in the evolution of international environmental law." International Affairs 88, no. 3 (2012): 605623.

. "The principle of common but differentiated responsibility and the balance of commitments under the climate regime." Review of European Community and International Environmental Law 9, no. 2 (2000): 120-131.

Rajamani, Lavanya, dan Jutta Brunnée. "The legality of downgrading nationally determined contributions under Paris agreement: Lessons from the US disengagement." Journal of Environmental Law 29, no. 3 (2017): 537-551.

Rajamani, Lavanya, dan Emmanuel Guerin. "Central Concepts in the Paris Agreement and How They Evolved." In The Paris Agreement on Climate Change: Analysis and Commentary, diedit oleh Daniel R. Klein, 75. New York: Oxford University Press, 2017. 
Sands, Philippe. Principles of International Environmental Law. 2nd ed. Cambridge: Cambridge University Press, 2003.

Savaresi, Annalisa. "The Paris Agreement: a New Beginning?" Journal of Energy \& Natural Resources Law 34, no. 1 (2016): 16-26.

Shishlov, Igor, Romain Morel, dan Valentin Bellassen. "Compliance of the Parties to the Kyoto Protocol in the First Commitment Period." Climate Policy 16, no. 6 (2016): 768-782.

Stern, Todd. "The Paris Agreement and its Future." The Brookings Institute 5 (2018): 7.

Tarigan, Vita Cita Emia, dan Eka N.A.M Sihombing. "Kebijakan Pengendalian Pencematan di Selat Malaka yang bersumber dari Kecelakaan Kapal.” Jurnal Penelitian Hukum De Jure 19, no. 4 (2019): 470-502.

UNFCCC. "COP26: Postponed." Last modified $2020 . \quad \mathrm{https} / / /$ unfccc.int/news/cop26postponed. -."Decision 1/CP.17 FCCC/ADP/2015/1." In Ad Hoc Working Group on the Durban Platform for Enhanced Action Second Session FCCC/ADP/20, 3, 2015.

. "Lima call for climate action." Decision COP 20 (2014): 1-43. https://unfccc.int/files/ meetings/lima_dec_2014/application/pdf/ auv_cop20_lima_call_for_climate_action. pdf.

. "Technical Paper for UNFCCC "Tracing the Origins of the Kyoto Protocol: an Articleby-Article Textual History FCCC/ TP/2000/2," 2000 .

—. "The Kyoto Protocol - Status of Ratification.” Diakses Juni 22, 2019. https:// unfccc.int/process/the-kyoto-protocol/ status-of-ratification.

United Nations (UN). Kyoto Protocol of the united nations framework convention on climate change. United Nations Treaty Series 2303, 2005.

. Paris Agreement. United Nations. United Nations Treaty Series 54113, 2015.
"Report on the Conference of the Parties on its Seventh Session Addendum Part Two: Action Taken by the Conference of Parties FCCC/CP/2001/13/Add.2,"2002.

United Nations Conference on the Human Environment Stockholm Declaration: A/ CONF.48/14/Rev.1, 1973. https://www. un.org/ga/search/view_doc.asp?symbol=A/ CONF.48/14/REV.1.

\section{United Nations Framework Convention} on Climate Change. United Nations Treaty Series 1771, 1992.

Victor, David G. The Collapse of the Kyoto Protocol and the Struggle to Slow Global Warming A Council on Foreign Relations Book. Princeton University Press. Berkeley: Princeton University Press, 2001.

Voigt, Christina, dan Felipe Ferreira. "Dynamic Differentiation: The Principles of CBDR-RC, Progression and Highest Possible Ambition in the Paris Agreement." Transnational Environmental Law 5, no. Fifth Anniversary Issue (2016): 285-303.

Wara, Michael. "Measuring the Clean Development Mechanism's erformance and Potential." UCLA Law Review 55, no. 6 (2004): 1759-1803.

Weiss, Edith Brown. "Environmental Equity: The Imperative for the Twenty-first Century." In Sustainable Development and International Law, diedit oleh W. Lang. London: Martinus Nijhoff Publishers, 1995.

Yamin, Farhana, dan Joanna Depledge. The International Climate Change Regime: A Guide to Rules, Institutions and Procedures. Cambridge: Cambridge University Press, 2004.

Yusyanti, Diana. "Tindak Pidana Pembakaran Hutan dan Lahan oleh Korporasi untuk Membuka Usaha Perkebunan." Jurnal Penelitian Hukum De Jure 19, no. 4 (2019): 455-478. 
